\title{
A STUDY OF THE NATURE OF THE CIRCULATING THYROID HORMONE IN EUTHYROID AND HYPERTHYROID SUBJECTS BY USE OF PAPER ELECTROPHORESIS ${ }^{1}$
}

\author{
By WILLIAM P. DEISS,2 EDWIN C. ALBRIGHT, AND FRANK C. LARSON \\ (From the Department of Medicine of the University of Wisconsin Medical School, \\ Madison, Wis.)
}

(Submitted for publication June 23, 1952; accepted August 22, 1952)

The physico-chemical form in which the secretion of the thyroid gland exists in blood is not well understood. It is generally believed to be associated in some manner with the plasma proteins since the iodine content of precipitated washed plasma protein (1) and the rate of turnover of $\mathrm{I}^{131}$ in this protein appears to vary with the state of thyroid activity (2). The observation of Trevorrow (3) that this "protein bound" or "hormonal iodine" is readily extractible with butanol from unhydrolysed serum indicates that it is not bound by a peptide linkage.

The introduction of the technique of paper electrophoresis combined with the use of $\mathrm{I}^{131}$ as a tracer isotope has afforded a new and valuable instrument for a study of the problem $(4,5)$. With this technique it has been demonstrated that after 24 to 48 hours there is a characteristic localization of administered $\mathrm{I}^{131}$ in the alpha globu-

1 This study was supported in part by the Wisconsin Alumni Research Foundation.

2 Research Fellow of the Arthritis and Rheumatism Foundation.

3 The radioactive iodine used in this study was obtained from the Isotopes Division of the Oak Ridge National Laboratory of the Atomic Energy Commission, Oak Ridge, Tenn. lin moiety although the exact location is still somewhat in doubt (4-6). It is the purpose of this paper to study further this localization and to compare euthyroid and hyperthyroid subjects particularly with regard to the turnover of iodine in these two groups over a period of several days.

\section{CLINICAL MATERIAL}

The six patients selected for this study were seen in the Department of Medicine of the University of Wisconsin. Thyroid function was measured by determination of serum protein bound iodine by the method of Barker (7), and by the 24-hour uptake of $\mathrm{I}^{12}, 1$ as reported previously (8). Pertinent clinical data are summarized in Table I. Three patients were hyperthyroid as judged by their classical symptoms, physical findings, elevated PBI, and $\mathrm{I}^{131}$ uptake. Three patients were euthyroid as judged by similar criteria, but were given radioactive iodine therapy for incapacitating cardiac disease. In each instance therapeutic quantities of carrier-free $\mathrm{I}^{181}$ ranging from 5 to $23 \mathrm{mc}$. were administered orally. These doses were calculated to deliver the same amount of radiation ( 75 to $100 \mu \mathrm{c} / \mathrm{gm}$.) to the gland in all subjects. This estimation was based upon previous uptake studies of "tracer" quantities of $\mathrm{I}^{181}\left(100 \mu_{\mathrm{c}}\right.$ ) and upon the size of the gland.

Upon completion of the diagnostic studies and administration of the radioactive iodine, blood samples were drawn at daily intervals, placed in dry centrifuge tubes, and the serum separated for paper electrophoresis.

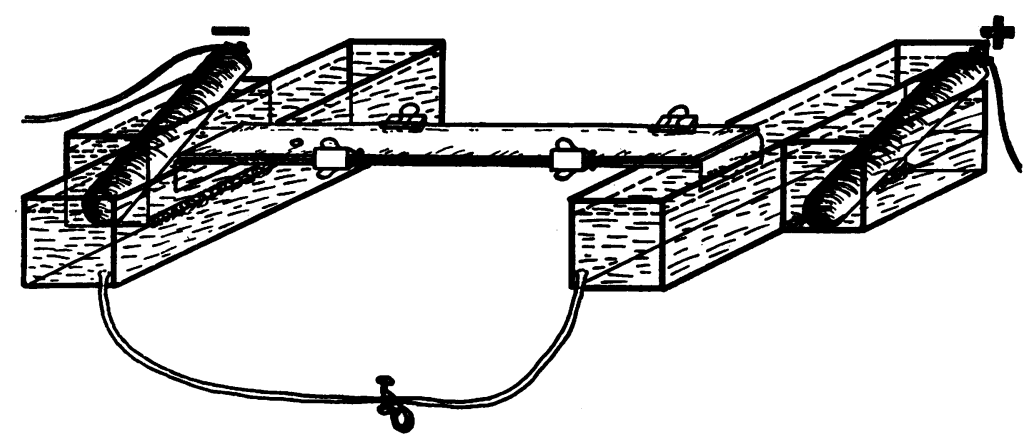

Fig. 1. Sketch of the Paper Electrophoresis Apparatus

Described in text. 
TABLE I

Summary of clinical data

\begin{tabular}{|c|c|c|c|c|c|c|c|}
\hline Patient & Age & Sex & Diagnosis & Physical findings & $\begin{array}{l}\text { Protein } \\
\text { bound } \\
\text { iodine* }\end{array}$ & $\begin{array}{c}\text { I131 } \\
\text { Uptaket } \\
\text { at } 24 \text { hrs. }\end{array}$ & $\underset{\text { tered }}{\mathrm{I}^{131}}$ \\
\hline 1. (C. S.) & 19 & $\mathrm{~F}$ & Hyperthyroidism & $\begin{array}{l}\text { Diffuse goiter. Estimated wt. } \\
75 \mathrm{gm} .\end{array}$ & $\begin{array}{c}\mu g m . \% \\
11.1\end{array}$ & $58 \%$ & $\begin{aligned} & m c . \\
& 8\end{aligned}$ \\
\hline 2. (M. V.) & 47 & F & Hyperthyroidism & $\begin{array}{l}\text { Diffuse thyroid, barely palpable. } \\
\text { Estimated wt. } 30 \mathrm{gm} \text {. }\end{array}$ & 11.3 & $51 \%$ & 5 \\
\hline 3. (J. W.) & 45 & $\mathbf{M}$ & Hyperthyroidism & $\begin{array}{l}\text { Diffuse goiter. Estimated wt. } \\
60 \mathrm{gm} .\end{array}$ & 10.2 & $61 \%$ & 7 \\
\hline 4. (N. R.) & 57 & $\mathbf{M}$ & $\begin{array}{l}\text { Euthyroid } \\
\text { Hypertensive, arteriosclerotic } \\
\text { heart disease } \\
\text { Old myocardial infarct } \\
\text { Angina decubitus }\end{array}$ & $\begin{array}{l}\text { Thyroid not palpably enlarged. } \\
\text { Estimated wt. } 25 \mathrm{gm} \text {. }\end{array}$ & 5.0 & $15 \%$ & 16 \\
\hline 5. (E. S.) & 50 & $\mathbf{F}$ & $\begin{array}{l}\text { Euthyroid } \\
\text { Hypertensive heart disease } \\
\text { Paroxysmal auricular fibril- } \\
\text { lation }\end{array}$ & $\begin{array}{l}\text { Diffuse thyroid, barely palpable. } \\
\text { Estimated wt. } 30 \mathrm{gm} \text {. }\end{array}$ & 7.3 & $38 \%$ & 9 \\
\hline 6. (V. D.) & 34 & $\mathbf{F}$ & $\begin{array}{l}\text { Euthyroid } \\
\text { Luetic heart disease } \\
\text { Aortic insufficiency } \\
\text { Cardiac enlargement } \\
\text { Massive anasarca }\end{array}$ & $\begin{array}{l}\text { Thyroid not palpably enlarged. } \\
\text { Estimated wt. } 25 \mathrm{gm} \text {. }\end{array}$ & 4.8 & $15 \%$ & 23 \\
\hline
\end{tabular}

* Normal range PBI 4 to $8 \mu \mathrm{gm} . \%$.

$\dagger I^{131}$ uptake expressed as per cent of the dose present in the thyroid at 24 hours. (Euthyroid range, 10-40\%; hyperthyroid, over $50 \%$.)

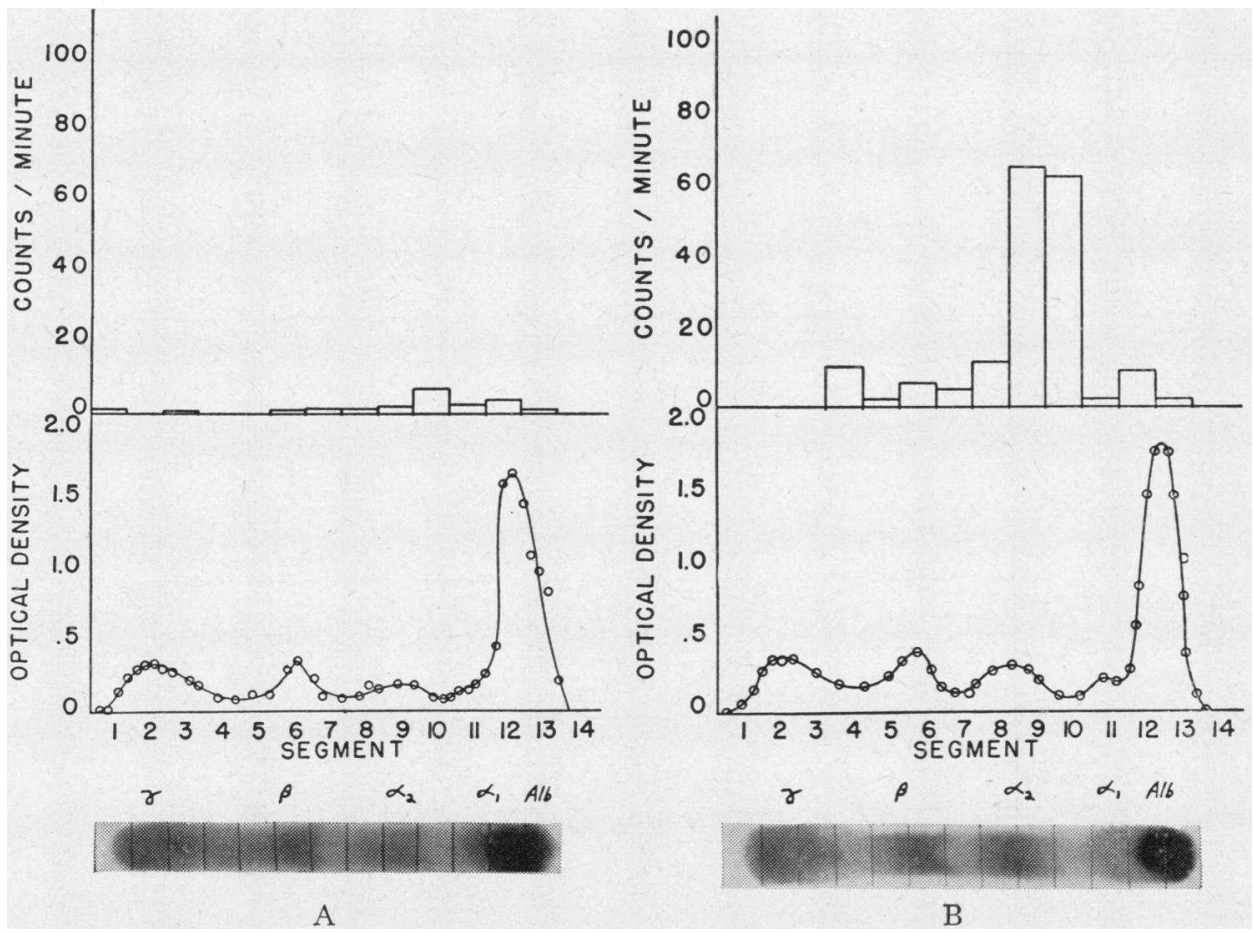

Fig. 2. Localization of Protein-Bound ${ }^{131}$ by Paper Electrophoresis in a Euthyroid (A) and a Hyperthyroid (B) Patient, Eight and Two Days Respectively, After I ${ }^{131}$ Administration

The bottom strips are photographs of the stained paper strips. The middle graphs represent the protein concentration of the strips (dye elution method). The top graphs show the relative radioactivity of the segments. 


\section{METHODS}

1. Filter paper electrophoresis. The method of Kunkel and Tiselius (9) was employed with a few modifications. A strip $(3.5 \times 45 \mathrm{~cm}$. $)$ of Schleicher and Schuell No. 598 filter paper was soaked in $0.05 \mathrm{M}$ veronal buffer, $\mathrm{pH} 8.6$, and clamped between two glass plates $(3.8 \times 35 \mathrm{~cm}$.) after rolling the paper heavily with a photographic roller in order to remove excess buffer and air spaces. The glass plates were first covered with a thin coat of silicone grease and the sides of the plates were sealed together with the grease after the filter paper was clamped in place. The plates were then placed across a pair of leucite buffer vessels, each containing 1 liter of the veronal buffer with the free ends of the paper dipping into the buffer (Figure 1). A period of one hour was allowed for equilibration of the buffer on the paper. The equilibration and actual electrophoresis were done in a cold room at $2^{\circ} \mathrm{C}$. Carbon electrodes were introduced into separate vessels filled with buffer, the latter being connected to the
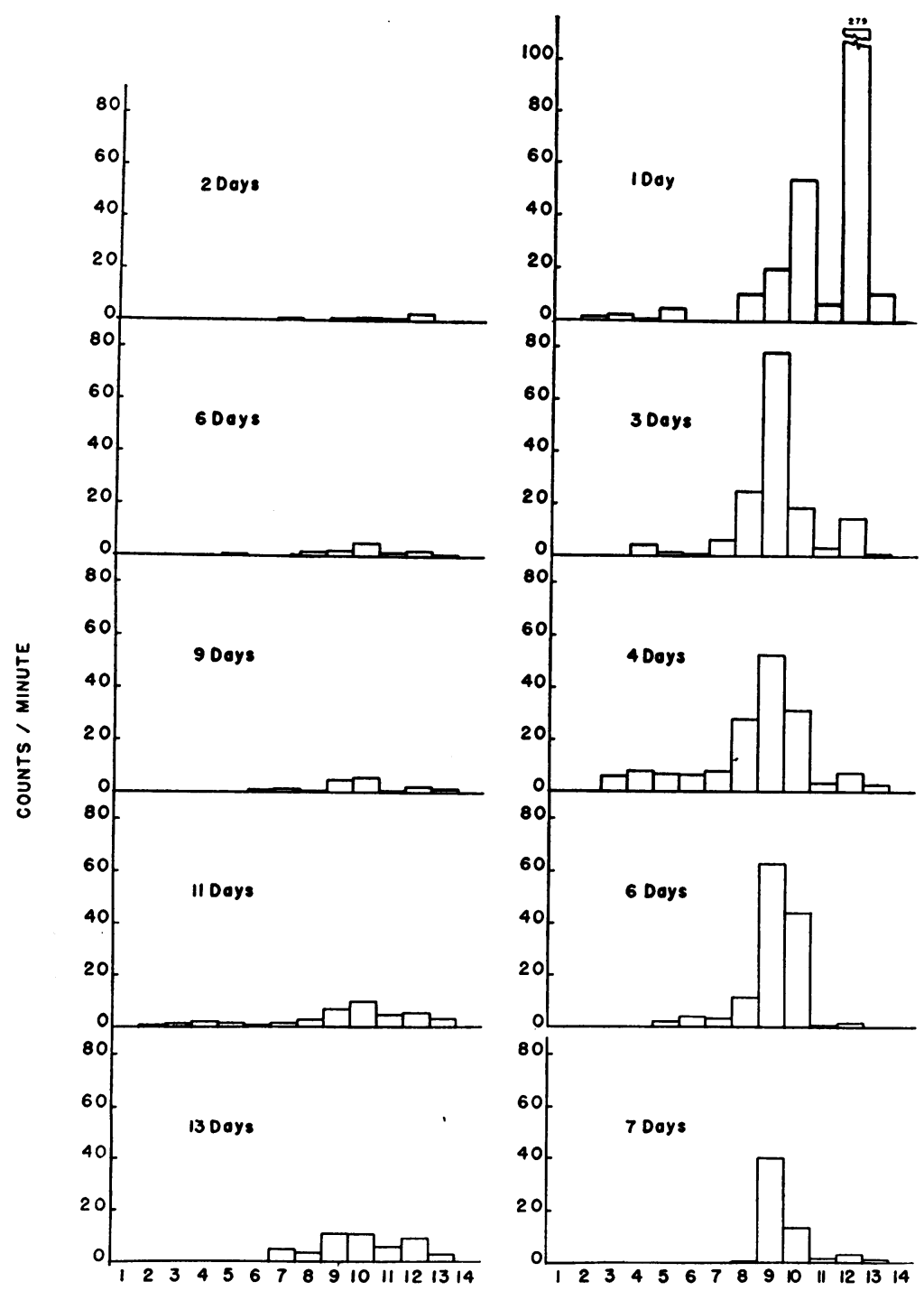

SEGMEN T

A
B

Fig. 3. Comparison of Serial Radioelectrophoretograms in a Euthyroin (A) and a Hypertiyroid (B) Patient

The radioactivity was normalized for dose of $\mathrm{I}^{131}$ and corrected for isotopic decay. 
main buffer vessels through a slot filled with glass wool to prevent $\mathrm{pH}$ changes during the operation. Fifty lambda of serum were introduced to the paper strips through a small hole in the upper glass plate $9 \mathrm{~cm}$. from the cathodal end and allowed to drain evenly into the paper. After 30 minutes a potential of 300 volts D.C. was placed across the electrodes. With this system approximately 1 milliampere will pass through each paper strip. Twenty hours were allowed for resolution at this current and the strips were then removed.

2. Counting technique. At the completion of the electrophoresis the strip was dried in an oven at $80^{\circ} \mathrm{C}$. The dried strip was then divided transversely into fifteen $2 \mathrm{~cm}$. - segments, using for purposes of consistent orientation the starting point of the electrophoresis. The first segment was cut exactly $5 \mathrm{~cm}$. toward the cathodal end from this point, thus placing the starting point of electrophoresis in the center of segment three. The radioactivity of each segment was determined with a mica window bell-type Geiger counter using a slotted leucite sample holder which assured reproducible positioning. A minimum of 500 counts per segment was recorded.

3. Quantitative estimation of protein. After the segments were counted they were subdivided into $0.5 \mathrm{~cm}$. sections and the protein bands identified and quantitated by the bromphenol blue elution method (9).

\section{RESULTS}

Figure 2 represents the radioelectrophoretograms of representative euthyroid and hyperthyroid patients. The radioactivity is located in two major zones, which are identical in both subjects. One zone is centered in the slowest moving portion of the albumin (segment 12), but distinctly ahead of the alpha-1 fraction. The other is just ahead of the alpha- 2 fraction in an area of relatively low protein concentration (segments 9 and 10). This distribution of radioactivity was observed in all the patients studied.

Although the radioactivity is confined to the same two zones in both the euthyroid and hyperthyroid subjects there is a distinct difference in the absolute and relative concentration at these two sites in these two groups. This is particularly striking when serial radioelectrophoretograms done at daily intervals are compared (Figure 3 ). In these two series the radioactivity measurements were normalized (standardized to correct for differences in the quantity of $\mathrm{I}^{131}$ administered) and corrected for decay. The total radioactivity is much greater in the hyperthyroid than in the euthyroid subject throughout the series. Initially, most of the radioactivity is associated with the albumin fraction in both the euthyroid and hyper-

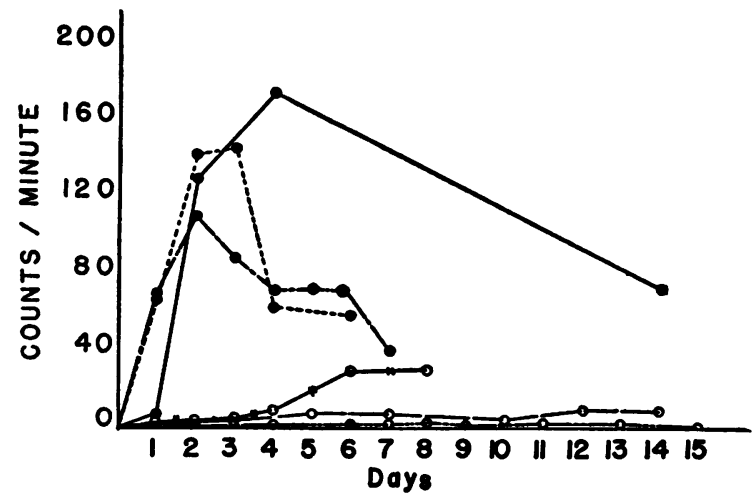

Fig. 4. Relationship of Radioactivity in Alpha Globulin (Segments 9 and 10) to the Time Interval After Administration of $I^{131}$ in ThreE HyperthyroId (Solid Dots) and Three EuthyroId (OpEN Dots) SubJeCts

The radioactivity was normalized for dose of $\mathrm{I}^{181}$ and corrected for isotopic decay.

thyroid subjects. However, the radioactivity at this site in the hyperthyroid subject declines rapidly. In the euthyroid subject, on the other hand, although the initial albumin-bound radioactivity was small, it increases progressively. With the rapid decline of radioactivity bound to albumin in the hyperthyroid subject, there is a rapid reciprocal rise in radioactivity at the alpha globulin zone (segments 9 and 10). The activity at this alpha globulin zone in the euthyroid subject is initially low and increases gradually. Figure 4 compares the turnover of $\mathrm{I}^{131}$ at the alpha globulin zone in three euthyroid and three hyperthyroid subjects.

\section{DISCUSSION}

During the first few hours after the administration of $I^{131}$, most of the radioactivity rapidly passes off the paper strip toward the anode $(4,5)$. It is assumed that this fraction is free iodide ion since this is the behavior which would be expected of a small negatively charged ion. Serial radioelectrophoretograms demonstrate that the radioactivity remaining on the strip, and hence presumably "protein-bound," increases progressively so that at the end of the three days all but a small fraction remains on the strip (5).

The concentration of $\mathrm{I}^{\mathbf{1 3 1}}$ in the albumin fraction soon after its administration is believed to represent partial binding of the iodide by this protein, whose ion-binding capacity is well known. This 
assumption is supported by in vitro studies in which $\mathrm{Na} \mathrm{I}^{131}$ was added to serum. A radioelectrophoretogram showed significant localization of radioactivity in the albumin fraction even though the greater part moved faster than albumin and was assumed to be the unbound radioactive "I" ion. This observation has been reported previously by Gordon and his associates (4). The observation that the albumin of hyperthyroid subjects bound and released $\mathrm{I}^{131}$ at more rapid rates than the albumin of euthyroid subjects may reflect a more rapid turnover of total body iodine in hyperthyroid subjects.

In both euthyroid and hyperthyroid subjects the major portion of the albumin bound iodine is associated with the slowest moving portion of albumin suggesting a difference in iodine binding capacity within the albumin fraction. This differential iodine binding within the albumin fraction is consistent with Salter's observation (10) that the greater part of the PBI was in Cohn's fraction VI which contains the smaller albumin molecules.

The rapid shift of $\mathrm{I}^{131}$ to the protein fraction having electrophoretic mobility slightly faster than alpha-2 globulin (sections 9 and 10) in the hyperthyroid patients and the slower but significant $\mathrm{I}^{131}$ concentration in the same area in euthyroid subjects, suggests that the circulating thyroid hormone is, or is associated with, this alpha globulin fraction. The unequivocal localization of iodine to this fraction by paper electrophoresis is in contrast to earlier reports (11) indicating that hormonal iodine was associated with albumin. Most of this investigation was done using ammonium sulphate protein fractionation. It is now known that much of the alpha globulin is precipitated with albumin by this method. Analysis of Cohn's globulin fractions, however, has indicated a high iodine-to-protein ratio in fraction IV-2 which contains largely alpha globulins (10).

Present evidence indicates that the biologically active iodine fraction in blood is a thyroxine-like substance $(3,12)$ complexed with a plasma protein. In vitro experiments (4) demonstrate that radio-thyroxine added to plasma becomes bound to an alpha globulin, supporting the view that the circulating thyroid hormone may be a thyroxinealpha globulin complex.
It is generally believed that patients with hyperthyroidism have a quantitative rather than a qualitative difference in the circulating iodine compounds $(13,14)$. Chromatographic analysis of iodine-containing compounds in protein fractions separated by paper electrophoresis should give valuable additional information.

The possibility that accumulation of radioiodine in the alpha- 2 area is due to artefact attendant upon radiation damage to the thyroid gland has been considered. The demonstration by Robbins and his associates (15) that a rise in serum PBI and an increase in the ratio $\mathrm{PBI} /$ butanol-extractible iodine after administration of large doses of $\mathrm{I}^{131}$, might seem to support this possibility. We believe this unlikely for the following reasons: 1) All subjects both euthyroid and hyperthyroid received the same concentration of $\mathrm{I}^{131} / \mathrm{gm}$. tissue; 2) Robbins and his associates report no change in the $\mathrm{PBI} /$ butanol extractible iodine ratio in their subjects who received doses of $I^{181}$ comparable to those given in the present report; 3 ) When radiothyroxine is added to serum in vitro it appears in the alpha globulin area (4).

\section{SUMMARY AND CONCLUSIONS}

1. The sera of three euthyroid and three hyperthyroid subjects have been studied using $\mathrm{I}^{131}$ as a tracer isotope and paper electrophoresis for separating the major plasma protein components.

2. After twenty-four hours the radioactivity localized in two major zones, one in the slowest moving albumin and the other in a zone of low protein concentration just ahead of alpha- 2 globulin. This localization was seen in both euthyroid and hyperthyroid subjects.

3. Soon after administration of $\mathrm{I}^{131}$ most of the radioactivity was associated with the albumin fraction but in the hyperthyroid individual there was a rapid shift to the alpha region. A similar though considerably slower shift occurred in the euthyroid subjects.

4. Present evidence indicates that the hormonal iodine is carried by the alpha globulin fraction. The tracer iodine concentrated faster, attained higher levels, and declined more rapidly at this site in the hyperthyroid than in the euthyroid subjects. 


\section{REFERENCES}

1. Salter, W. T., and Bassett, A. M., A physiological interpretation of blood iodine fractions in terms of thyroid function (in 100 cases). Tr. A. Am. Phys., 1941, 56, 76.

2. Sheline, G. E., and Clark, D. E., Index of thyroid function: Estimation by rate of binding of $\mathrm{I}^{121}$. J. Lab. \& Clin. Med., 1950, 36, 450.

3. Trevorrow, V., Studies on the nature of the iodine in blood. J. Biol. Chem., 1939, 127, 737.

4. Gordon, A. H., Gross, J., O'Connor, D., and PittRivers, R., Nature of the circulating thyroid hormone-plasma protein complex. Nature, 1952, 169, 19.

5. Larson, F., Deiss, W. P., and Albright, E. C., Localization of protein-bound radioactive iodine by filter paper electrophoresis. Science, 1952, 115, 626.

6. Winzler, R. J., and Notrica, S. R., Association of thyroxine with plasma proteins. Federation Proc., 1952, 11, 312.

7. Barker, S. B., Humphrey, M. J., and Soley, M. H., The clinical determination of protein bound iodine. J. Clin. Invest., 1951, 30, 55.
8. Albright, E. C., and Middleton, W. S., The uptake of radioactive iodine by the thyroid gland of leukemic patients. Blood, 1950, 5, 764.

9. Kunkel, H. G., and Tiselius, A., Electrophoresis of proteins on filter paper. J. Gen. Physiol., 1951, $35,89$.

10. Salter, W. T., The metabolic circuit of the thyroid hormone. Ann. N. Y. Acad. Sc., 1949, 50, 358.

11. Bassett, A. M., Coons, A. H., and Salter, W. T., Protein-bound iodine in blood. V. Naturally occurring iodine fractions and their chemical behavior. Am. J. M. Sc., 1941, 202, 516.

12. Taurog, A., and Chaikoff, I. L., The nature of the circulating thyroid hormone. J. Biol. Chem., 1948, 176, 639.

13. Gross, J., and Pitt-Rivers, R., The identification of $3: 5: 3^{\prime}$-L-triiodothyronine in human plasma. Lancet, 1952, 1, 439.

14. Gross, J., and Pitt-Rivers, R., Physiological activity of 3:5:3'-L-triiodothyronine. Lancet, 1952, 1, 593.

15. Robbins, J., Rall, J. E., Becker, D. V., and Rawson, R. W., The nature of the serum iodine after large doses of I's. J. Clin. Endocrinol., \& Metab., 1952, $12,856$. 